HStud 26 (2012)2, 233-240 DOI: 10.1556/HStud.26.2012.2.4

\title{
THE HIDING HUMANIST - IOANNES, THE GOOD FELLOW
}

\author{
PÉTER KŐSZEGHY \\ Institute for Literary Studies, Research Centre for the Humanities, \\ Hungarian Academy of Sciences \\ Budapest, Hungary
}

\begin{abstract}
The letter of Marsilio Ficino was published under the title Dubitatio utrum opera philosophica regantur fato an providentia and summarised his tenets of Platonist-Humanist philosophy as it were. Based on his book of letters, this writing is part of a correspondence in which Ficino responds to Ioannes Pannonius of Buda, who, in his letter to Ficino - also published by the book of letters - criticised Ficino's views. Literary criticism has been trying to identify the persona of Ioannes Pannonius for long. In the highly influential study of Florio Bánfi, Joannes de Varadino (Giovanni Unghero, Giovanni Varadino), that is, John of Várad, Augustine monk is identified as the supposed person. Bánfi's views were reconsidered by Klára Pajorin in 1999, who reckoned that Ioannes Pannonius is John Vitéz the Younger. The author of the present study wishes to enhance the idea of Valery Rees (1999) who thinks that Ioannes Pannonius was created as a fictitious character by Ficino, and thus, the author reckons that the letter came in handy primarily against Savonarola and his followers because the correspondent from Buda raises those very topics on the bases of which Ficino can elaborate the sole decorous model of behaviour, the path that should be followed by the fictitious addressee as well.
\end{abstract}

Keywords: Janus Pannonius, Ioannes Budeius Pannonius, Joannes Varadiensis, Marsilio Ficino, János Vitéz the Younger, the correspondence of Ficino, prisca theologia, Savonarola

Literary historiography keeps count of a contemporary of Janus Pannonius of a similar name, who, too, studied in Italy and was called Ioannes (Johannes) Pannonius. ${ }^{1}$ This Ioannes Pannonius, according to József Huszti, Paul Oscar Kristeller and others, wrote a letter to Marsilio Ficino at the end of 1484 or, most probably, in $1485 .^{2}$ He criticised Ficino because he did not consider the revival of pagan Greek philosophy and the practice of astrology necessary for a true Christian religion. In his reply, Ficino defended his views and published both pieces of writing in the edition of his letters. ${ }^{3}$

Hungarian and international literature trod different paths. The former wished to identify the man behind the name of Janus Pannonius first and foremost, while 
the latter was especially interested in Ficino's reply and the elaborated world view.

It was Huszti who distinguished the famous poet Janus and Ioannes for the first time. ${ }^{4}$ In research, the study of Florio Bánfi meant a great step forward (or backwards?). ${ }^{5}$ On the one hand, he composed a rather monographic picture from the mosaics of known data, and on the other hand, he made a new observation: he discovered that a poem in a Vatican codex had been written to János Váradi - presumably on his request - by Giunio Gradi. From the title note of the poem Pulchrum Responsum Junii De Gradis $M$ Hit is R. fratrj Joanni De Varadino Interroganti - however, one can only read this and not more; it is only a daring supposition that - as Bánfi thought - frater Joannes de Varadino, or Giovanni Unghero, or Giovanni Varadino, that is, János Váradi, the Augustine friar is no other person than Ioannes Pannonius.

Bánfi's hypothesis formed the well-known biography. ${ }^{6}$ He reckoned to have known three writings of Ioannes: the letter to Ficino, a commentary to the Song of Songs and a rhyming poem in Latin.

The attribution of the above works to Ioannes Pannonius is, however, not unproblematic. This was noticed by Klára Pajorin already in her 1999 study, ${ }^{8}$ in which she doubted whether the writer of the Song of Songs commentary was the Ioannes Pannonius who wrote a letter to Ficino, and she also thought that Ioannes Pannonius was identical with János Vitéz the Younger and not János Váradi.

It is a fact that out of the four known manuscripts of the Song of Songs commentary, only the Munich version in the royal library (the present Bayerische Staatsbibliothek) alludes to the Hungarian author. As Bánfi writes,

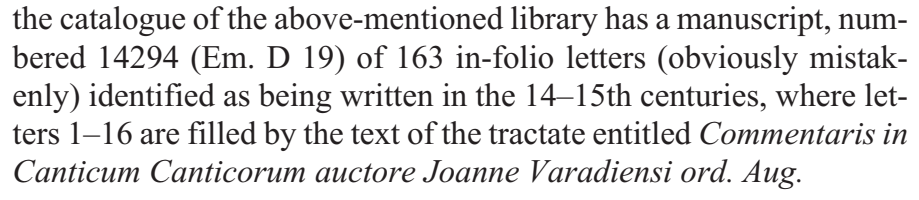

The time-frame "14-15th centuries", which is somewhat contradictory to the authorship of Ioannes who wrote the letter to Ficino is swept away by Bánfi with no explanation. In the other three cases ${ }^{9}$ (Einsiedeln, Stiftsbibl. 33, 336-361; London, Lambeth Palace 180, 1-43; Reun, Cisterciens. 76, 125-150), there are also rifts in the lute: the 15th century London manuscript names Ioannes Russell of Canterbury (from the Order of Friars Minor) as the author of the commentary, while the Reun manuscript is considered to be from the 14th century. Bánfi - ex cathedra-declares that the attribution, the dating is incorrect.

This is the first and foremost reason for Klára Pajorin to - rightfully - deny that Ioannes who wrote a letter to Ficino and the Ioannes who commented on the Song of Songs were the same. 
We should add that the other work attributed to Ioannes Pannonius by Bánfi, the rhyming poem, is known from the 13th century (it is usually attributed to Jacopone da Todi); not only the incipit (Cur mundus militat sub vana gloria) is identical, but also the entire chant. It was István Hegedüs in 1900 who took notice of the poem when he stumbled upon a chant entitled Cantio Joannis Pannonii contra amatores mundi in the manuscript department of the Viennese Bibliotheca Palatina. ${ }^{9} \mathrm{He}$ found out that the codex that included the chant was edited by Jesuits at the end of the 16th century and that its author could not be Janus Pannonius. The Cur mundus militat... was first published in the book of chants of Gál Huszár (1574) in Latin and Hungarian (Mit bizik ez világ ö álnokságában...). Péter Bornemisza - we do not know which tradition he based his views on - also attributed the text to Janus.

István Borsos called attention to things to be corrected already in $1900,{ }^{10}$ when he showed that the text is definitely older than the 15th century.

Klára Pajorin finds Ioannes Pannonius in the person of János Vitéz the Younger. However, this identification is not convincing either. Klára Pajorin's biography of János Vitéz the Younger ${ }^{11}$ partly fits the Pannonius who wrote a letter to Ficino, the one who considers the ideas of Theologica platonica dangerous for the faith, and the choice of name can be well explained, too, but there is no decisive proof for either the János Váradi-Ioannes Pannonius identification or an identification with other contemporary Johns of Hungary. Some biographical data do not by all means match those written in the letter: the letter-writer Ioannes, for example, pins down that he is writing from Buda, while János Vitéz the Younger is King Matthias's envoy in Rome from 1480, and only returns to Hungary after the king's death (1490). This is somewhat contradictory to dating the correspondence to 1485 (based on arguments in the text and its position within the 8th volume), ${ }^{12}$ yet it is not questioned by Pajorin ${ }^{13}$ (and is accepted by international research ${ }^{14}$ after Kristeller).

"But who was the Hungarian correspondent of Ficino then? We do not know more about the person than what we know from the correspondence itself ${ }^{\prime 15}$ Bánfi wrote in 1968.

We do not know more even now. We have arrived back to Huszti: “... despite all the efforts of my research, I could not reasonably trace down his age, his occupation or his family etc." 16

The two letters use a similar terminology: "providentiae renovatio antiquorum theologia" is a keyword in that of Pannonius and also "renovatio antiquorum" at another place; in Ficino's: "renovatio divinae providentiae". They agree on renovatio, but Pannonius sees the renovation of antique theology, whilst Ficino sees that of (Christian) divine providence in this process.

In the preface to his translation of Plotinus (1492) Ficino wrote: "factum est, ut pia quaedam philosophia quondam et apud Persas sub Zoroastre et apud 
Aegyptios sub Mercurio nasceretur", ${ }^{17}$ and in the letter mentioned above, he expressed himself in exactly the same way, word by word. ${ }^{18}$ The textual identity of the two works might indicate that these texts were written not too far in time from one another. The entire preface to the Plotinus translation and the letter's line of thought are the same: they discuss the manifestation of God in history, the chain of ancient theology (prisca theologia); the golden chain that goes from Zoroaster and Hermes Trismegistos, via Plato as the peak to Jesus and the Church Fathers, up until Ficino's present; it is a syncretistic tradition, a sort of new apology, in which symbolical order is more important than that of chronology.

Based on the above, it is not unimaginable (though cannot be proved) that the correspondence was written after 1485 when Ficino increasingly needed an apology for himself against Savonarola: most probably around 1487-1488. At a time when Pico, too, wrote his own Apology (1487). And even more so, when Ficino writes an Apology (1488) against Savonarola in which he depicts the Dominician friar as the utmost hypocrite, the Anti-Christ himself. ${ }^{19}$

Therefore, the letter of Ioannes Pannonius is the golden opportunity for Ficino to express, elaborate and defend his views. Cannot this obliging Ioannes Pannonius be a figure of mere fiction? ${ }^{20}$

No-one has ever seen the handwritten letter itself. A manuscript collection of these letters and the printed edition were both created in Ficino's lifetime, and a manuscript could be provided by him and by no-one else. If he wished to express his views against potential enemies (and his apology is a proof for that), he could not have found a better occasion. It is very characteristic that the provoking letter is only one-third of the reply, and it cannot be a coincidence either that in the 1497 edition I used, there are no marginalias near the letter of Ioannes Pannonius, but there are indeed numerous for Ficino's reply.

The writing of Ioannes Pannonius is an odd-one-out. Ficino's collection of letters, as the letters of every humanist, contain studies, teachings as well as philosophical, theological and medical writings, ${ }^{21}$ we very rarely find something not written by Ficino, but to Ficino; if there is any writing of such sort, there is always a special reason for it, most often - as with the Medici - prestige. The Janus-Ficino correspondence is unlike the Ficino-style epistola familiaris. Also, the reprehension of Ficino by a Hungarian letter-writer is the only such letter in the corpus, distinct in its tone.

Hungarian humanists have not received too many letters from Ficino anyway, ${ }^{22}$ and none of their letters are included in Ficino's collection of letters (with the sole exception of Ioannes - if we consider him Hungarian and a humanist). Not even the correspondence with Janus Pannonius the poet, who was no doubt greatly appreciated by Ficino, but the letters of whom were - rightfully - considered a mutual sign of appreciation, a supplement of sent works, a recommendation, something unfitting for the purposes and concept of a collection of letters. 
Ficino wrote this towards the end of his letter: "Quoniam vero te Poëtarum apprime studiosum esse cognosco, rem totam una cum Marone concludam."23 And he continued:

Aeneas, id est, heroicus animus descensurus ad inferos, et iterum ascensurus, id est, secreta divinorum mysteria penetraturus, et obscura editurus in lucem, divina ad hoc ipsum providentia ducitur tanquam et divinitus (ut ait) genitus, quem et aequus amabat Iupiter, et divina ad idem oracula provocabant. Incedit rursus ad idem libero quodam arbitrio, ubi eum ardens evehit ad aethera virtus, et ubi consultat, quid potissimum sit agendum, et sponte oracula consulit, et semper libentissime cum sententia divina consentit. Confert ad idem fatum providentiae serviens ab oraculo designatum. ${ }^{24}$

Who is this heroicus animus, who is Aeneas here? It is the Platonist-humanist philosopher himself. The one and only worthy model of behaviour is described here, the path followed by Ficino and the path that should be followed by the addressee, too. The golden bough should be obtained, in a way described by Virgil's sibyl; Ficino's letter continues, as promised, quoting Virgil:

carpe manu; namque ipse volens facilisque sequetur, / si te fata vocant; aliter non viribus ullis / vincere, nec duro poteris convellere ferro. $^{25}$

This is a credo and a parable for the addressee at the same time, an exemplum. ${ }^{26}$ The part that comes after the quotation explains the harmony of providentia and fatum, whilst sentences preceding the goodbye formula rhetorically describe the primacy and importance of (divine) providence, what Ficino summarised in a letter to Bandini (that directly precedes the Ioannes Pannonius letter in the collection of letters) as follows: "Ita profecto iubet deus omnipotens hac nos divina providentia ducit, hac ergo sequamur."

Hopefully, Ficino's letter landed in fertile soil, Pannonius ${ }^{27}$ accepted the true idea and became a heroicus animus. After all, he received an answer to each and every one of his questions. Also, he helped the master with criticism as both fatum and divina providentia and became a catalyst for his teachings. And such a good fellow should have been invented, if there ever was none.

Notes

\footnotetext{
Not as a poet, on official documents, Janus Pannonius also used the "Ioannes" form. The correspondence of Ioannes Pannonius and Ficino was first noticed by Sándor Kovásznai Tóth (1730-92) who copied it from the printed edition of Ficino's works (Marsilii Ficini Opera om-
} 
nia, Basileae, 1576) into the so-called Carmina inedita (Marosvásárhely [Târgu-Mures], Teleki Téka, MS 305).

2 Ioannes Pannonius writes his letter after reading Ficino's Platonica theologia de immortalitate animorium (1482), Platonis's Opera (1484) and Ficino's letter to Bandini, hence the terminus post quem: the end of 1484 or the beginning of 1485, and the same excludes the authorship of the Janus Pannonius who died in 1472. Cf. Bánfi, Florio (1968) 'Ioannes Pannonius Giovanni Unghero: Váradi János' ItK, 194, note 12. Huszti puts the writing of the letter to 1485 (Huszti, József (1930) ‘Tendenze platonizzanti nella corte di Mattia Corvino’ Giornale critico della filosofia Italiana, 156) and so does Kristeller. Paulus Oscarius Kristeller (1937 [reprint: 1973]) Supplementum ficinianum, I, Florentiae, Olschki, CLVII.

3 Marsilii Ficini Florentini Epistolae familiares, Venetiis, Matteo Cadeca, 1495. (11 March), lib. VIII, epist. 17-18. The edition I used: Epistolae Marsilii Ficini Florentini, Antonius Koberger, 1497 (23 February), CXXXI-CXXXII (http://hardenberg.jalb.de/display_page. php?elementId=926. Modern edition: Ábel, Jenő and Hegedűs, István (1903) Analecta nova ad historiam renascentium in Hungaria litterarum spectantia (Budapest), 278 (the letter of J. P.), 279-81 (the reply of M. F.).

4 Huszti, József (1924) 'Platonista törekvések Mátyás király udvarában’ Minerva, Vol. 111, 216-22; Huszti, József (1930) 'Tendenze...' ibid., 155-6. (In international literature, there are still attributions of the letter to Janus Pannonius the poet.)

5 Bánfi ibid., 194-200.

6 The Új magyar irodalmi lexikon (New Hungarian Encyclopaedia of Literature) also accepts the identification with János Váradi (entry by György Gömöri). The Katolikus lexicon (Catholic Encyclopaedia) (http://lexikon.katolikus.hu/) goes even further: "János Váradi, OSA (Várad, County Bihar, ca. 1430): friar - 1449-54: educated in Várad. 1455: the abbot allowed the continuation of his studies. Went to Florence, where he studied Latin, Greek and astrology [!], met Marsilio Ficino [!]. 1463: came home from Florence and worked in the monastery of his order, in Buda. He started the translation of Plato's works to Latin [!]. He wrote a commentary to the Song of Songs. V. S. (1968) ItK, 194. (Bánfi, Florio: Ioannes Pannonius - Giovanni Unghero: Váradi János) - Tonk 1979: 259. (1028.)" I put exclamation marks after statements that are unproved and unprovable, which are not from Bánfi.

7 Pajorin, Klára (1999) 'Ioannes Pannonius e la sua lettera a Marsilio Ficino' Verbum: Analecta neolatina, Vol. 1, 60-9.

8 On the manuscripts: Stegmüller, Fridericus (1951) Repertorium Biblicum Medii Aevi, III, Commentaria (Matriti), 438, No. 5028. Bánfi's reference, ibid., 196, notes 21-2.

9 Hegedűs, István (1900) 'Ioannes Pannonius éneke' ItK, Vol. 10, 243-5. Bánfi (ibid., 195, note 14), also refers to it. Katona, Lajos (1900) “'Ioannes Pannonius éneké”-hez’ EphK, Vol. 24, 468-9 - but I could find no such writing of Katona either on the place referred to or anywhere else, it may have been mixed up with the Borsos study that is mentioned in the next footnote, though it refutes Bánfi's theory.

10 Borsos, István (1900) “'Ioannes Pannonius éneké”-hez’ ItK, Vol. 10, 468-9.

11 Pajorin, ibid., 66.

12 Manuscript sources cannot be dated accurately. The one-time Corvina can now be found in Wolfenbüttel (Marsilius Ficinus, Epistolarum ad amicos libri VIII, cum praefatione Philippi Valoris ad Matthiam regemHungariae) and is most often said to be written in 1489, primarily because of the recommendation to King Matthias Corvinus and its subject-matter. The codex contains all the letters of Ficino from 1488-89. Cf. http://diglib.hab.de/wdb.php?dir= $\mathrm{mss} / 73$-aug-2f\&pointer $=563$. The general dating of the Florentine manuscripts: the second half of the 1480s. Kristeller puts the eighth part of the collection of letters, which includes the 
correspondence, between 1484 and 1488, I tend to place the Janus letter and the reply between this timeframe, too. Cf. Kristeller, ibid., I. CII.

13 The most well-known researcher of Ficino, Michael J. B. Allen's book (Synoptic Art: Marsilio Ficino on the History of Platonic Interpretation, Florence, Leo S. Olschki Editore, 1998 [Studi e testi 40]) discusses in its first chapter Ficino's favourite idea, the "prisca theologia", among others in the context of the Ioannes Pannonius-Ficino correspondence. He univocally recites the Bánfi concept of Pannonius = Augustine friar, moreover, he points out Augustinian ideas in J. P.'s letter. John Monfasani's review of the book raises no objections against it either: (http://jps.library.utoronto.ca/index.php/renref/article/viewFile/10711/7619). Valery Rees (Ad vitam felicitatemque: Marsilio Ficino to His Friends in Hungary, http://www.btk. ppke.hu/uploads/files/1-1-07), exactly because of these arguments finds Bánfi's theory more probable than Pajorin's: "The original Janus Pannonius, Bishop of Pecs, had been dead for a decade. The identity of this new John the Hungarian has been the subject of various suggestions of which the two leading contenders are Janos Varadi [...] and Janos Vitez the younger, Bishop of Szerem and, like his relative the famous Janus Pannonius, also a nephew of Matthias' great Chancellor also called Janos Vitez [...]. Yet Michael Allen's demonstration of the strong Augustinian basis of the views expressed rather favours Banfi's earlier proposal." In my opinion, it might be because Bánfi's article was published in Hungarian after the author's death, and international literature took cognizance of it, but - due to linguistic reasons did not check its arguments. And if the author is an Augustinian friar, it is almost sure that Augustinian ideas (too) can be shown in his writings. And then, an argumentation is already reversed: it is exactly these Augustinian ideas that make an unsubstantiated identification feasible.

14 "... letter of 1485 to Janus Pannonius in Hungary" (cf. Davies, Clement Salaman 'Echoes of Egypt in Hermes and Ficino' in Michael J. B. Allen, Valery Rees and Martin Davies (eds) (2002) Marsilio Ficino: His Theology, His Philosophy, His Legacy (Leiden, Koninklijke Brill NV), 117); “... In Ficino's well-known letter toJanus Pannonius of the mid 1480s..." [Celenza, Christopher S. (1999) 'Pythagoras in the Renaissance: The Case ofMarsilio Ficino' Renaissance Quarterly].

15 Bánfi, ibid., 195.

16 Bánfi cites Huszti, ibid.

17 Opera omnia, Basel, 1576; reprinted: Turin, 1962, 1537.

18 This has been noticed by many, e.g., Davies, Echoes... ibid., 117.

19 Cf. http://smu.edu/bridwell tools/specialcollections/bridwellwesternms/ms34.htm. The manuscript (Apologia Marsilij Ficini pro multis florentinis ab antichristo Hieronimo Ferrariense, hypocritar [um] summo deceptis: ad collegiu[m] Cardinalium) can be found in the Bridwell Library (Southern Methodist University), its facsimile and relevant literature on the homepage, its modern edition: Kristeller, ibid., II, 76-9. Cf. Selected Writings of Girolamo Savonarola: Religion and Politics, 1490-1498, eds Anne Borelli, Donald Beebe, Maria C. Pastore Passaro, Giuseppe Mazzotta (New Haven: Yale University Press, 2004), 355-6 (Post-mortem - Marsilio Ficino: the chapter entitled Apologia contra Savonarola).

20 Valery Rees has already suggested something very similar (in 1999) : "I would like to suggest a further possibility, that this vigorous exchange may represent an imaginary engagement, either with the earlier and famous Janus Pannonius, or indeed with one of the other candidates. Ficino would have perhaps composed the letter from Janus himself." Rees ibid.

21 It is very characteristic how the De vita libri tres manuscript is formed: the three books had originally been three different manuscripts: the De vita sana (or De cura valetudinis eorum qui incumbunt studio litterarum), the De vita longa and the De vita coelitus comparanda. By the end of the $1480 \mathrm{~s}$, De vita sana had more than one existing manuscript versions, and to this, 
Ficino attached the beginning of the seventh book of his epistles: epistles became incorporated into the studybook-coursebook volume without any genre obstacles.

22 Cf. Rees, ibid., 73. “...to Nicholas Bathory, the Bishop of Vac, Ficino sent three letters, to Peter Varadi one letter, to a Janus Pannonius, whose identity has been much discussed, there is one letter, a response to one included from him, though this may be a literary device. Peter Garazda is mentioned but receives no letters, King Matthias is the recipient of five. This makes ten letters in all, to Hungarians at Matthias' court - not a large number."

23 "And, for I know you as a studious researcher of poets, I shall conclude with Maro."

24 "Aeneas, that is, the heroic soul will descend into the underworld and will arise again, that is, he will penetrate secret mysteries of divination and will bring light obscure things to light, as someone who was born - as is said - on divine suggestion, loved by Jupiter the Just and called upon the same by divine prophecies. He enters the same place from a different point (of view), arbitrarily, where his flaming virtue will lift him to the skies, where he contemplates on what he should do of all things, he will consult an oracle by his own will and happily consents to divine sentence. Serving it, he always advances the fate designated by providence."

25 Aeneid, VI, 146-8. "take it, of right, in your hand: since, if the Fates have chosen you, / it will come away easily, freely of itself: otherwise you / won't conquer it by any force, or cut it with the sharpest steel..."

26 Tricky advice. For we know that despite the prophecy of Sibyl, the bough does not break voluntarily, by the call of fate it even bends away (cunctantem) from Aeneas, who then tears it off, something he should not conquer by force, not even the sharpest steel: "corripit Aeneas extemplo auidusque refringit / cunctantem, et uatis portat sub tecta Sibyllae." (Aeneid, VI, 210-11) We should not regard it as a mere coincidence that Ficino plays with this well-known contradiction. Cf. Segal, Charles (1968) 'The Hesitation of the Golden Bough: A Reexamination' Hermes, Vol. 96, 74-9.

27 The letter subtly indicates that this Pannonius is not that Pannonius, he has no title, as opposed to Janus, the Bishop of Pécs; he is Ioannes Budeius Pannonius who lives (if he lives or lived) in Buda, in the distant Hungary - while in other letters, there is usually no indication of the place at all. 